Н. Г. Майборода

\title{
ЛЕКСИКА ХУДОЖНІХ ТВОРІВ Д. ЯВОРНИЦЬКОГО: СЕМАНТИЧНА СТРУКТУРА ТА СТИЛІСТИЧНІ ФУНКЦЇ̈
}

\begin{abstract}
Майборода Н. Г. Лексика художніх творів Д. Яворницького: семантична структура та стилістичні функції.

У статті проаналізована лексика художніх творів Д. Яворницького 3 погляду особливостей використання як загальновживаних лексичних номінацій, так і лексики вузького стилістичного призначення; описані тематичні групи, які автор використовує для змалювання життя i побуту українського селянства.
\end{abstract}

Ключові слова: загальновживана лексика, побутова лексика, професійно-виробнича лексика, розмовна лексика, діалектизми, вульгаризми.

Майборода Н. Г. Лексика художественных произведений Д. Яворницкого: семантическая структура и стилистические функции.

В статье осуществлён анализ лексики художественных произведений Д. Яворницкого с точки зрения особенностей употребления как общеупотребительных лексических номинаций, так и лексики узкого стилистического назначения; описаны тематические группы, которые автор использовал для изображения жизни и быта украинского крестьянства.

Ключевые слова: общеупотребительная лексика, бытовая лексика, профессиональная лексика, разговорная лексика, диалектная лексика, вульгаризмы.

Maiboroda N. G. Vocabulary of the works by D. Yavornitsky: semantic structure and stylistic functions.

The article is devoted to the analysis of the vocabulary of the works by D. Yavornitsky from the point of view of the peculiarities of the word usage vernacular language and vocabulary of a narrow stylistic values; the thematic groups of the current vocabulary nominations for the description of the Ukrainian peasants are described.

Key words: commonly used vocabulary, the household lexicon, professional vocabulary, speaking vocabulary, dialect vocabulary, vulgar.

Дмитро Іванович Яворницький - одна 3 найвизначніших постатей наукового й культурного життя України другої половини XIX - першої половини XX століття. Його творча та наукова спадщина має непересічне значення для розвитку української гуманітарної науки, а також для відродження історичної пам'яті й національної самосвідомості українського народу. Він відомий як історик, письменник, археолог, фольклорист, етнограф, лексикограф. Багатогранна особистість Д. Яворницького не обділена увагою вчених, але його художня спадщина 
не була об'єктом лінгвістичних пошуків. Викладене вище зумовлює актуальність дослідження мовного творчого доробку Д. Яворницького. Мета нашої статті - дослідити словник ідіостилю Дмитра Яворницького 3 погляду тематичної мотивації і народнорозмовного джерела вживаної письменником лексики, виявити особливості ії функціонування в художніх текстах автора. Поставлена мета передбачає розв'язання таких завдань: розмежувати лексичні одиниці за сферами вживання та за стилістичними ознаками, визначити лексико-семантичний діапазон кодифікованих мовних одиниць.

Лексика художніх творів Д. Яворницького багата й різноманітна.

Обрана письменником тематика творчості (зображення усіх сторін життя народу) спонукала до використання із зображувально-виражальною метою всіх лексичних ресурсів національної мови. Д. Яворницький був прихильником комплексного вивчення народного життя. Він уважав, що тільки шляхом старанного студіювання народної словесності, у тісному зв'язку з побутом народу можна зрозуміти його «душу і серце». За справедливим зауваженням академіка Л. Булаховського, часто «етнографічний матеріал саме і $є$ той ключ, з допомогою якого лінгвістетимолог відкриває для себе і для тих, хто цікавиться його роботою, ті зв'язки матеріальних мовних асоціацій, які справді існували в житті і які без допомоги відповідного етнографічного матеріалу відтворювались би при етимологізуванні тільки суб'єктивно-гіпотетично, намацувались би, а не встановлювались би впевнено на основі надійного матеріалу» [1, с. 84].

Прибічник етнографізму, шанувальник деталей, точного відтворення побуту, Д. Яворницький і в художніх творах залишався етнографом. Свої прозові твори він вважав «прямо-таки етнографією», «списаною 3 живих людей» [4, с. 254]. Збірку оповідань «Поміж панами» автор назвав «малюнки 3 життя». «Читайте и не думайте, что то моя выдумка, те типы, которые у меня выведены, фотографически списаны с живых лиц. Может быть, некоторых из них и сами узнаете», - писав він І. Рєпіну в січні 1927 року [3, с. 205].

Основою мови художніх творів Д. Яворницького є загальновживана лексика, якою він досконально володів і використовував як у розмовній, так і в писемній практиці. На думку Д. Дорошенка, письменник виявив «справжній талант реаліста-побутовця» [2, с. 165]. Побутова лексика найширше представлена в художніх творах Д. Яворницького. Найбільш чисельною є група найменувань одягу, головного вбрання, взуття (а також ïx деталей) різних соціальних верств тогочасного суспільства: штани, сукні, сорочки, галстук, шаль, кожух, пальто, хустка, капелюх, картуз, шапка, панчоха, чоботи, ботфорти, кишеня, комір, підтяжка, халяви . Розкішне вбрання та жіночі прикраси детально описано з характеристикою якісних ознак, вказівкою на дорогу тканину, різноманітне оздоблення: Галя швидко накидає на плечі князівни легку, пухку, коштовну ротонду 
[7, с. 497]; ...nідходе до скринь і спериу витягає з них золоті, з неоцінними самоцвітами, перстені, далі итучне, столітнє, коштовне кружево, $у$ якому вона колись-то щзе стояла на шлюбі, потім коштовні иовкові, 3 чудовою обробою, сукні, далі дивної роботи сережки; за сережками оксамитові, з золотою ниткою, пояси, за поясами на рідкість дороге і на рідкість коштовне діамантове кольє; після того легкі і граціозні полуботики; опріч того м'які, як пушина, шовкові панчішки і нарешті білосніжні лайкові рукавички [7, с. 495]. Деталізації опису сприяє використання родовидових відношень між словами: До такого зросту щзе й вбрання: каптан з високим, стоячим коміром, на два вуси ззаду, з бабками та гапликами спереду, шапка на голові висока та гострагостра, така, щзо й грім не влуче [7, с. 548]. Іменник «вбрання» виступає гіперонімом щодо іменників «каптан» і «шапка», у свою чергу лексема «каптан» $\epsilon$ гіперонімом щодо іменників «комір», «бабка», «гаплик», оскільки останні позначають елементи одягу.

Досить чисельною є група назв будівель та їх частин, пов’язаних із сільським побутом та господарюванням. Серед них можна виокремити назви житлових приміщень: хатина, флігель, будинок, опочивальня, вітальня, зала, господа, прихожа, галерея, кімната, мезонін, віконниці, наличники, балкон; назви господарських будівель та споруд: клуня, обора, голубник, хлів, колодязь, курінь, кухня, горище, погріб, стріха, піч, тин, стайня, комора, саж, млин, хвіртка, ворота; назва будівель - закладів певного спрямування: корчма, шинок, крамниця, лазня, каземат. Д. Яворницький також вживає назви хатніх речей та їх частин: віник, рядно, подушка, скриня, ослін, цүеберка, відро, стілещьь, лава, лежанка, ліжко, лежак, канапа, комод, підлокітник.

Уживання назв частин одягу, споруд чи будівель допомагає створити детальний, майже фотографічний опис людини чи місцевості. Сільське господарство неможливе без домашніх тварин та птахів, i назви їх використані у творах Д. Яворницького: качка, гуска, індик, півень, курка, квочка, порося, корова, бугай, жеребечь. Саркастично зображуючи надмірне захоплення пана Шпаківського (оповідання «Собачий хутір i його вельможний пан Цуцало») розведенням собак, автор подає довгий ланцюжок назв собачих порід: Tym тобi: вівчарки, сибірські лайки, муцики, хорти, гончаки, меделяни, британи, такси, бернари, келенджоги, бульдоги, фокстер'єри, кінгчарлси i інші [7, с. 456]. Як бачимо, в одному ряду подано як загальновживані назви, так і розмовні (муцик - мопс), а також не зареєстровані ні в сучасних, ні в словниках того часу - британ, бернар (імовірно, сенбернар), келенджог.

Висміюючи безпомічність, безгосподарність деякої частини українського панства (оповідання «Великі земські діячі, або пани Сонцелови»), письменник уводить в мовну тканину твору назви порід коней: Добродіï, ви бачили того сементала? Трясия то, а не сементал! ... 
Ти розпізнаєш справжнього сементала від холмогора? - Та нехай він тобі западеться, той сементал! Розпізнай, який у мене у стайні стоїть жеребецьь. Найчистіший арден! [7, с. 529]. Зображувані пани легко оперують сільськогосподарською термінологією, щоб створити образ багатого й досвідченого господаря. Але такими вони є лише у власній уяві.

До побутової лексики відносимо також назви речовин та матеріалів: пшоно, солома, прядиво, сургуч, сталь, шовк, перкаль, амбра; назви посуду та різноманітних ємностей: горщик, ложка, казанок, черепочки, чавун, миска, полумисок, казан, тарілка, макітра, виделка, барильце, боклажка, діжка, кадібка, корито; назви транспортних засобів, використовувані на той час, та їх частин: екіпаж, бричка, хура, голобля.

Досить поширеною є тематична група, до якої входять назви страв та напоїв: вареники, чай, проскурка, борщ, каша, булка, сухарі, бублики, молоко, суп, оселедецьь, кнельки, пиріжки, горбушка, скоринка, лушпайка, вино, горілка, квас, мелясівка; а також харчових продуктів, із яких вони виготовлені: масло, цукор, борошно. Іноді описи досить інформативні, 3 указанням сортів та видів продукції, відтворюють не тільки різноманітність страв, а й вказують на соціальний стан і рівень життя персонажа, який їх уживає: нарізати молодої лососинки та баличка, поставити свіжої зернястої, без волоконецьь, ростовської, або щуе смачніше петровської ікриці [7, с. 494].

Для відтворення різноманітних сторін життя селян автор використовує народні назви танців і пісень: Хіба ушкварити щце полтавочки, або торбини, або ж жидівського триндика? [7, с. 447]. Словник сучасної української мови не фіксує слів «полтавка» $\mathrm{i}$ «торбина» в ужитому значенні.

Професійно-виробнича лексика охоплює назви знарядь праці, спеціальностей, трудових процесів тощо, як-от: струг, верстак, обруч, клепка, граблі, різка, черезсідельник.

Змальовуючи занепад домашнього господарства одного з персонажів збірки оповідань «Пани Сонцелови», Д. Яворницький вдається до детальних описів господарського інвентаря: I ото в середині тієї повітки поскладано було усяке хліборобське орудіє: дерев'яний, так званий украӥнський плуг; далі рамсоновський плуг на шість пар волів; потім, шуось таке схоже чи на англо-болгарський, чи на саковський, чи на геновський плуг, а чи на всі три вкупі, видимо зроблене власним майстром і у власній кузні; потім дерев'яні рала, букарі, борони ще з дерев'яними, замість залізних, кілками; дерев'яні лопати для віянки [7, с. 523]. Означення "рамсоновський», «англо-болгарський», «саковський», «геновський», використані для порівняння 3 «українським дерев'яним», підкреслюють недосконалість названих сільськогосподарських інструментів.

У художніх творах Д. Яворницького використана професійновиробнича лексика різних галузей життя, зокрема фінансова: банк, 
відсотки, десятина, ссуда, недоїмка; юридична: прокурор, слідство, злочин, слідчий, справник; військова: полк, солдат, москаль, гільдія, командир, штик. Іноді така лексика пов'язана із сюжетом твору, із конкретним персонажем. Семен Дурда (роман «За чужий гріх») був богомазом, свого сина також хотів навчити цьому ремеслу. Тому ву його мовленні наявні лексеми, що є назвами професійних матеріалів або дій: помазок, пензлик, масло, ладан, лой, краски мінеральні, хімічні і циньові охра, мумія, сурик, блейвас, крон, кульфарба, золото, мат, яр; прошпакльовати, пролінтрикувати, випемзувати, вишахтанувати, прополюментувати. Описуючи діяльність земського лікаря, автор вживає лексику для позначення хворобливих станів: гнилещь, куряча сліпота, заморока рогової плівки, крихкість кісток, роздуха черева, блідниия, безсоння, віспа, гарячка.

У своїх творах Д. Яворницький порушував питання виховання, освіти, культурного розвитку українців, тому закономірним $\epsilon$ використання абстрактної лексики на позначення суспільних явищ, процесів чи станів: мораль, розум, ученість, творчість, прогрес; професійної лексики, пов'язаної з навчанням: університет, аудиторія, студент, декан, лекція, гімназія, професор, анатомія, фізика, мінералогія.

Окреме місце посідає релігійна лексика, адже релігія відігравала значну роль у житті українського народу: камилавка, скуфія, пояс, ряса, служба, боги, іконостаси, иерква, крилас, титар, вівтар, батюшка, образи, Великдень, Різдво, Псалтирь, Апостол, архієрей, протоієрей. Д. Яворницький свого часу був учнем Харківської духовної семінарії, звідси й така глибока обізнаність із церковною термінологією: канон (жанр церковної гімнографії), кафизма (богослужебний розділ Псалтиря, під час читання якого дозволялося сидіти), прокимен (вірш, який прочитують перед Священним Писанням), cmuхар (богослужебний одяг священнослужителів).

Церковно-книжна лексика вживається автором для характеристики персонажа: владика заставив Мусія Мусійовича вичитати напам'ять ледве не половину Псалтиря та Часловця, і Мусій Мусійович, вичитавии, «побідоносно» повернувсь од владики додому $i$ «в прах сокрушив свого супостата» [7, с. 51], Мусій Мусійович ... бував інколи «під титлою», Ось я вас живо візьму у скобки! [7, с. 58]. Поєднання в одному контексті загальновживаної лексики із спеціальною надає висловленню гумористичного відтінку. Д. Яворницький використовує вирази «бував під титлою», «візьму у скобки» для характеристики образу дяка Мусія Мусійовича, який був священною особою й навчав сільських дітей грамоті.

Словник мови Д. Яворницького вирізняється використанням розмовної лексики. Серед іменників виявлено назви речей: запіл (пола одягу), кавалок (шматок), рептух (мішок з кормом для коней); абстрактних понять: кебета (розум), озія (щось надто велике, незграбне), труднація; 
процесів: балачка; частин тіла людини: патли, пика, пузо. У складі розмовної лексики вирізняються іменники, які називають осіб та їх вчинки, засвідчують зневагу, фамільярність, лайливість: чортяка, харцизяка та ін.

Серед прикметників домінують такі, що позначають особливості характеру, вдачі, інтелекту, фізичні ознаки: капосний, кебетливий, напиндючений, опецькуватий, плохий (тихий, сумирний).

Розмовні дієслова означають назву дії (гайнути, замамотіти, навратитися (пристати до кого-небудь, вимагаючи чогось), напиндючитися, прошпетитися, розлупатися (розкрити очі), слебезувати (недоброзичливо обговорювати кого- чи що-небудь), телесуватися, товкмачити, ухекати (убити), ушкварити), пересування й переміщення (віддухопелити, відтаскати, шатнутися (метнутися), швендяти).

Серед розмовної лексики виявлено значну кількість прислівників (буцімто, духом (швидко), знарочно, навперебивки, навтікача, ондечки, осьдечки, тутечки, хватькома).

Експресивно-емоційні лексеми (безщасний, славнесенька, хлопчина, страшенний, страховище, замурзана, довбешка) передають значеннєві відтінки співчуття, захоплення, приязного ставлення чи навпаки - зневаги, докору, презирства, лайливості; через них здійснюється влучна характеристика соціальних і психологічних типів людей.

Як бачимо, розмовна лексика $\epsilon$ одним iз найважливіших стилістичних компонентів мовотворчості Д. Яворницького.

Д. Яворницький послуговується також просторічною лексикою, оскільки вона надає художньому мовленню народного колориту, збагачує його, є одним 3 важливих засобів реалістичного зображення побутових ситуацій. Автор використовує слова, перекручені 3 погляду існуючих норм: абаркоси, гамазин, кандріль, Капказ, кумедія, лапорт, охвіцерський, niдnебель, филозопія; слова із різко зниженим експресивним забарвленням: бельбас, лоботряс, дурандос, остолоп, бидло; вирази просторічного вжитку: понаставляти каганціi [7, с. 45], підкувати ухналями [7, с. 38], в потилицюю накласти [7, с. 343], стовбура стати [7, с. 346], на витрібалах ставати [7, с. 542]; вульгаризми, лайливу лексику: Анахтем! Гамазон, харизизяка! Зарізяка! Тьфу на твою погану мацуалку! [7, с. 539]; Так постій же ти, чортова свічка [7, с. 533]; А нехай же їй трясия! [7, с. 489]; росіянізми: вредно, город, лучче, небезпременно, офиціальная часть, плясати, прежній, хазяйство, харош, умісті. Письменник відтворював їх поширення в реальній мовній практиці, використовував як засіб характеристики персонажів. Водночас росіянізми в художніх творах Д. Яворницького відбивають процеси, характерні для мовленнєвої ситуації південно-східного регіону України. Російською мовою автор наводить цитати $з$ офіційних документів, подає назви офіційних посад чи установ, відтворює мовлення росіян, а також українців, які з різних причин мусили вживати російську мову. Д. Яворницький відобразив мову різних 
суспільних верств населення такою, якою вона була в його часи.

Зі стилістичною метою автор уживає діалектизми. Слід відзначити, що більшість діалектних лексем ужито в мовленні автора: карватка, примусія, проїстливий, итепний, цуркий, банити, банітувати (лаяти когось), воложити (бити), кукобити, принатуритися, найпослі, найпаче, тілько, скілько. Це пояснюється як тематикою творчості письменника, так i його особистими настановами, демонстрацією своєї близькості до народних мас.

Об’єктом спеціального опису в творах Д. Яворницького є людина i навколишній світ. Найменування людини в текстах його художніх творів $\epsilon$ високочастотними і комунікативно значущими, його пейзажі інформативні й називають природні реалії, характерні для описуваної місцевості [5; 6].

Отже, з погляду сучасної загальнолітературної норми лексика творів письменника розподіляється між трьома групами: загальновживана нормативна лексика, стилістично маркована лексика та слова, не кодифіковані сучасною літературною мовою. Аналіз лексичного матеріалу свідчить про те, що Д. Яворницький в основному орієнтувався на живе народне мовлення жителів Слобожанщини, звідки він був родом. Лексика його творів є засобом відтворення національного колориту, створення психологічної й соціальної характеристики персонажів. Найбільш характерною ознакою оповіді Д. Яворницького $\epsilon$ тяжіння до побутописання, тому найактивніше в авторському словнику функціонує лексика, пов’язана із селянським побутом, працею. Серед цієї лексики особливий статус мають розмовні, діалектні, рідковживані лексичні одиниці, які автор використовував із стилістичною метою. У мовній тканині художніх творів письменника натраплясмо на слова, не зафіксовані у словниках української мови. Такі лексеми можуть бути самостійним матеріалом для дослідження мови його творів у контексті мовно-літературної практики кінця XIX - початку XX століття.

\section{Література}

1. Булаховський Л. А. Стосунки мовознавства 3 іншими науками / Л. А. Булаховський // Мовознавство. - 1967. - № 5. - С. 82-86.

2. Дорошенко Д. Запорожський батько / Д. Дорошенко // Дніпрові хвилі. - 1913. - № 10. - С. 165.

3. Лист Д. І. Яворницького до І. Ю. Рєпіна (січень) 1927. // Епістолярна спадщина Д. І. Яворницького. Вип. 4 : Листи Д. І. Яворницького до діячів науки і культури. - Дніпропетровськ : АРТ-ПРЕС, 2005. $-500 \mathrm{c}$.

4. Лист Д. І. Яворницького до Є. Х. Чикаленка від 21.01.1909 // Епістолярна спадщина академіка Д. І. Яворницького. Вип. 4 : Листи Д. І. Яворницького до діячів науки і культури. - Дніпропетровськ : АРТ-ПРЕС, 2005. - $500 \mathrm{c}$.

5. Майборода Н. Г. Опис природи у художніх творах Д. І. Яворницького як компонент етнолінгвістичної картини світу / Н. Г. Майборода // Вісник Дніпропетровського університету : Науковий журнал. Серія: Мовознавство. - Вип. 14. - Дніпропетровськ : Вид-во ДНУ, 2008. - С. 166-172.

6. Майборода Н. Г. Номінація особи у художніх творах Д. Яворницького як фрагмент мовної картини світу / Н. Г. Майборода // Мова і культура : Науковий журнал. - Вип. 11. - Т. VII (119). - К. : Видавничий Дім Дмитра Бураго, 2008. - С. 45-52.

7. Яворницький Д. І. За чужий гріх : Роман, повість, малюнки з життя / Д. І. Яворницький. Дніпропетровськ : Січ, 2006. - 600 с. 